\title{
Evaluation of Biological Activity of Mastic Extracts Based on Chemotherapeutic Indices
}

\author{
RYUICHIRO SUZUKI ${ }^{1}$, HIROSHI SAKAGAMI ${ }^{2}$, SHIGERU AMANO ${ }^{2}$, KUNIHIKO FUKUCHI $^{3}$, \\ KATSUYOSHI SUNAGA ${ }^{1}$, TAISEI KANAMOTO ${ }^{4}$, SHIGEMI TERAKUBO ${ }^{4}$, HIDEKI NAKASHIMA $^{4}$, \\ YOSHIAKI SHIRATAKI ${ }^{1}$, MINEKO TOMOMURA ${ }^{2}$, YOSHIKO MASUDA ${ }^{2}$, SATOSHI YOKOSE $^{2}$, \\ AKITO TOMOMURA ${ }^{2}$, HIROFUMI WATANABE ${ }^{5}$, MASAKI OKAWARA ${ }^{5}$ and YOSHIHARU MATAHIRA ${ }^{5}$ \\ ${ }^{1}$ Faculty of Pharmacy and Pharmaceutical Sciences, Josai University, Sakado, Japan; \\ ${ }^{2}$ Meikai University School of Dentistry, Sakado, Japan; \\ ${ }^{3}$ Graduate School, Showa University, Tokyo, Japan; \\ ${ }^{4}$ St. Marianna University School of Medicine, Kawasaki, Japan; \\ ${ }^{5}$ Sunsho Pharmaceutical Co., Ltd., Fuji, Japan
}

\begin{abstract}
Background: Most previous mastic investigators have not considered its potent cytotoxicity that may significantly affect the interpretation of obtained data. In the present study, we re-evaluated several biological activities of mastic extracts, based on chemotherapeutic indexes. Materials and Methods: Pulverized mastic gum was extracted with $n$ hexane and then with ethyl acetate or independently with methanol or n-butanol. Tumor specificity (TS) of the extracts was determined by their cytotoxicity against human malignant and non-malignant cells. Antibacterial activity was determined by their cytotoxicity against bacteria and normal oral cells. Antiviral activity was determined by their protection of viral infection and cytotoxic activity. Cytochrome P-450 (CYP) 3 A4 activity was measured by $\beta$-hydroxylation of testosterone. Results: Ethyl acetate extract showed slightly higher tumor specificity $(T S=2.6)$ and one order higher antibacterial activity (selectivity index $(\mathrm{SI})=0.813)$ than other extracts (TS=1.4-2.5; SI=0.030-0.063). All extracts showed no antihuman immunodeficiency virus (HIV) activity, but some antiherpes simplex virus (HSV) activity, which was masked by potent cytotoxicity. They showed strong inhibitory activity
\end{abstract}

This article is freely accessible online.

Correspondence to: Ryuichiro Suzuki, Faculty of Pharmacy and Pharmaceutical Sciences, Josai University, Sakado, Saitama, 350-0295, Japan. Tel/Fax: +81 492718089, e-mail: ryu_suzu@josai.ac.jp and Hiroshi Sakagami, Meikai University Research Institute of Odontology (M-RIO), Sakado, Saitama 350-0283, Japan. Tel: +81 492792758, Fax: +81 492855171, e-mail: sakagami@dent.meikai.ac.jp

Key Words: Mastic, fractionation, ethyl acetate extraction, antibacterial, anti-HIV, anti-HSV, tumor specificity, CYP3A4 inhibition. against CYP3A4. Conclusion: Ethyl acetate extraction following the removal of cytotoxic and CYP3A4 inhibitory substances by $n$-hexane can enhance antitumor and antibacterial activity of mastic.

Mastic is the extract of sap from Pistacia lentiscus, grown only in the Chios island of Greece. Due to its unique shape and diverse efficacy, mastic has been called "the tear drop of Christ". Mastic extracts have been reported to show antitumor activity (including the enhancement of anticancer drugs' action and induction of apoptosis via oxidative stress) $(1,2)$, antioxidant activity (that correlated with phenolic and flavonoid contents) (3-8), antibacterial activity (9-11), modulating activity of drug-metabolizing enzymes $(12,13)$ and antiviral activity (14-17). However, most previous investigators did not describe the chemotherapeutic index of these activities (that is the ratio of the biological activity to cytoxicity), even though there is a cautionary note that mastic extracts showed potent cytotoxicity (18).

In the present study, we separated the crude mastic extract into 5 different fractions using organic solvents and, then, reexamined the biological activity of unfractionated and fractioned extracts, based on chemotherapeutic indexes.

\section{Materials and Methods}

Materials. The following chemicals and reagents were obtained from the indicated companies: Dulbecco's modified Eagle's medium (DMEM) (Gibco BRL, Grand Island, NY, USA); fetal bovine serum (FBS), 3-(4,5-dimethylthiazol-2-yl)-2,5-diphenyltetrazolium bromide (MTT), RPMI 1640 medium, doxorubicin, azidothymidine (AZT), 2',3'-dideoxycytidine (ddC) (Sigma-Aldrich Inc., St. Louis, MO, USA); dimethyl sulfoxide (DMSO) (Wako Pure Chemical Ind., Ltd., Osaka, Japan), curdlan sulfate (CRDS) (79 kDa; Ajinomoto Co. Inc., Tokyo, Japan). Culture plastic dishes and plates (96-well) were 
purchased from Becton Dickinson (Franklin Lakes, NJ, USA) Mastic was kindly provided by Sunsho Pharmaceutical CO., Ltd., Shizuoka, Japan.

Fractionation of mastic by organic solvent extraction. Pulverized mastic gum $(5 \mathrm{~g})$ was infused with $n$-hexane $(50 \mathrm{ml})$ at room temperature for $24 \mathrm{~h}$ to give $n$-hexane soluble fraction. Subsequently, the residue was re-extracted with ethyl acetate $(50 \mathrm{ml})$ by the same way to afford ethyl acetate soluble portion. Quite separate from this, pulverized mastic gum (5 and $10 \mathrm{~g}$ ) had been prepared and was infused with methanol (macerated) and $n$-butanol for $24 \mathrm{~h}$ at room temperature, independently. Furthermore, pulverized mastic gum (10 g) was extracted with methanol in reflux to prepare methanolic extract. The organic solvent of each soluble portion was evaporated under reduced pressure affording corresponding extract ( $n$-hexane extract, $2.1 \mathrm{~g}$; ethyl acetate extract, $2.4 \mathrm{~g}$; methanol extract (macerated), $3.6 \mathrm{~g}$; methanol extract (refluxed), $6.4 \mathrm{~g}$; and $n$-butanol extract, $9.0 \mathrm{~g}$ ).

Assay for cytotoxic activity. Human squamous cell carcinoma cell lines (Ca9-22, derived from gingiva and HSC-2, HSC-3, HSC-4 derived from tongue, all purchased from Riken Cell Bank, Tsukuba, Japan, and human normal oral cells [gingival fibroblast (HGF), periodontal ligament fibroblast (HPLF) and pulp cell (HPC)], established from the first premolar tooth extracted from the lower jaw of a 12-year-old girl (19), were inoculated at $2.5 \times 10^{3}$ cells $/ 0.1 \mathrm{ml}$ in a 96 -microwell plate. After $48 \mathrm{~h}$, the medium was replaced with $0.1 \mathrm{ml}$ of fresh medium containing different concentrations of each sample. Cells were incubated further for $48 \mathrm{~h}$ and the relative viable cell number was then determined by the MTT method (20). The relative viable cell number was determined by the absorbance of the cell lysate at $562 \mathrm{~nm}$, using a microplate reader (Infinite F50R, TECAN, Kawasaki, Kanagawa, Japan). Control cells were treated with the same amounts of DMSO and the cell damage induced by DMSO was subtracted from that induced by test agents. The concentration of compound that reduced the viable cell number by $50 \%\left(\mathrm{CC}_{50}\right)$ was determined from the doseresponse curve and the mean value of $\mathrm{CC}_{50}$ for each cell type was calculated from triplicate assays.

Tumor specificity index (TS) was calculated using the following equation: $\mathrm{TS}=$ mean $\mathrm{CC}_{50}$ against normal cells/mean $\mathrm{CC}_{50}$ against tumor cells $((\mathrm{D} / \mathrm{B})$ in Table I). Since Ca9-22 cells, as well as HGF cells, were derived from gingival tissue (21), the relative sensitivity of these cells was also compared ((C/A) in Table I).

Assay for antibacterial activity. Streptococcus mutans ATCC 25175, Escherichia coli ATCC 25922 and Staphylococcus aureus ATCC 25923 (all from American Type Culture Collection (ATCC), Manassas, VA, USA) were grown in Brain Heart Infusion (BHI) medium under aerobic conditions. Porphyromonas gingivalis 381 and Fusobacterium nucleatum ATCC 31647 were grown in Gifu Anaerobic Medium (GAM) containing $5 \mu \mathrm{g} / \mathrm{ml}$ hemin and $1 \mu \mathrm{g} / \mathrm{ml}$ menadione under anaerobic conditions with mixed gas of nitrogen $(83 \%)$, hydrogen $(7 \%)$ and $\mathrm{CO}_{2}(10 \%)$. Aerobic and anaerobic bacteria strains $\left(1 \times 10^{6}\right.$ colony-forming units $\left.(\mathrm{CFUs}) / \mathrm{ml}\right)$ were incubated at $37^{\circ} \mathrm{C}$ for 24 or $48 \mathrm{~h}$, respectively, in culture medium containing serially diluted mastic fractions or vehicle (DMSO), with the absorbance of the bacterial suspension being measured at 595 $\mathrm{nm}$. From the dose-response curve, the $50 \%$ inhibitory concentration of bacterial growth $\left(\mathrm{IC}_{50}\right)$ was determined. The selectivity index (SI) was determined by the ratio of $\mathrm{IC}_{50}$ to $\mathrm{CC}_{50}$ against human normal oral cells (D in Table I).
Assay for anti-human immunodeficiency virus (HIV) activity. The human T-cell leukemia virus I (HTLV-I)-bearing, CD4-positive, human T-cell line MT-4, established by Dr. Miyoshi (22), was cultured in RPMI-1640 medium supplemented with 10\% FBS and infected with HIV-1 ${ }_{\text {IIIB }}$ at a multiplicity of infection (MOI) of 0.01 . HIV- and mock-infected MT- 4 cells $\left(3 \times 10^{4}\right.$ cells/96-microwell) were incubated for 5 days with different concentrations of extracts and the relative viable cell number was determined by MTT assay. The concentration that reduced the viable cell number of the uninfected cells by $50 \%\left(\mathrm{CC}_{50}\right)$ and the concentration that increased the viable cell number of the HIV-infected cells to $50 \%$ that of control (mockinfected, untreated) cells $\left(\mathrm{EC}_{50}\right)$ were determined from the doseresponse curve with mock-infected and HIV-infected cells, respectively. The anti-HIV activity was evaluated by the SI, which was calculated using the following equation: $\mathrm{SI}=\mathrm{CC}_{50} / \mathrm{EC}_{50}$ (23).

Assay for anti-herpes simplex virus (HSV) activity. We performed the MTT assay to quantitate the anti-HSV activity of samples, as described previously (24). African green monkey kidney Vero cells (10,000 cells) were inoculated to a 96 well-plate (NUNC Labware Product-Sigma Aldrich Inc, Tokyo, Japan). After $24 \mathrm{~h}$, the cells were infected with HSV-1 (supplied by National Institute of Infectious Disease, Shinjukuku, Tokyo, Japan) (strain F) (MOI=0.01). HSV-1 and samples were pretreated for $20 \mathrm{~min}$ before added to the cells. After incubation for 4 days in $100 \mu \mathrm{l}$ MEM-10\% fecal calf serum, the cells were washed once with PBS, replaced with fresh culture medium that contained the MTT reagent (BioAssay Systems, Hayward, CA, USA) and then incubated for $4 \mathrm{~h}$. Cells were dissolved with $10 \%$ SDS in $0.01 \mathrm{M} \mathrm{HCl}$ and the absorbance was measured at $595 \mathrm{~nm}$. The anti-HSV activity was evaluated by the SI, which was calculated using the following equation: $\mathrm{SI}=\mathrm{CC}_{50} / \mathrm{EC}_{50}$. $\mathrm{CC}_{50}$ was determined with mock-infected cells. $\mathrm{EC}_{50}$ was defined as the concentration where the viability returned to the $50 \%$ that of mock-infected cells.

Measurement of CYP3A4 activity. CYP3A4 activity was measured by $\beta$-hydroxylation of testosterone in human recombinant CYP3A4 (Cypex Ltd., Dundee, UK). The reaction mixture, containing $200 \mathrm{mM}$ potassium phosphate buffer ( $\mathrm{pH}$ 7.4), NADPH regenerating system (1.3 mM NADPH, $1.3 \mathrm{mM}$ glucose-6-phosphate, $0.2 \mathrm{U} / \mathrm{ml}$ glucose-6phosphate dehydrogenase and $3.3 \mathrm{mM} \mathrm{MgCl}_{2}$ ) and the human recombinant CYP3A4 (16.5 pmol/ml) along with $0,1,3,11,33$ and $100 \mu \mathrm{g} / \mathrm{ml}$ of mastic (dissolved in DMSO), was pre-incubated at $37^{\circ} \mathrm{C}$ for $5 \mathrm{~min}$. The reaction was started by the addition of $300 \mu \mathrm{M}$ testosterone substrates. The final volume of the reaction mixture was $250 \mu \mathrm{l}$ with a final DMSO concentration of $2 \%$. The reaction was stopped by the addition of $500 \mu \mathrm{l}$ ethyl acetate after $15 \mathrm{~min}$. After centrifugation $(15,000 \times g$ for $5 \mathrm{~min}), 400 \mu \mathrm{l}$ of supernatant was collected, dried and re-suspended in $100 \mu$ l of methanol. Analyses of the metabolites were performed by high-performance liquid chromatography (HPLC) (JASCO PU2089, AS2057, UV2075

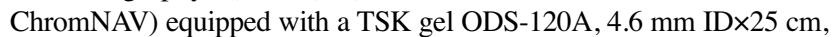
$5 \mu \mathrm{m}$ column (TOSOH, Tokyo, Japan). The mobile phase consisted of $70 \%$ methanol and $30 \%$ water. The metabolites were separated using an isocratic method at a flow rate of $1.0 \mathrm{ml} / \mathrm{min}$. Quantification of the metabolites was performed by comparing the HPLC peak area at $254 \mathrm{~nm}$ to that of $11 \alpha$-progesterone, the internal standard. The retention times for $6 \beta$-hydroxytestosterone and $11 \alpha$-progesterone were approximately 5.0 and $6.7 \mathrm{~min}$, respectively. The concentration that inhibited the CYP3A4 activity by $50 \%\left(\mathrm{IC}_{50}\right)$ was determined from the dose-response curve. 

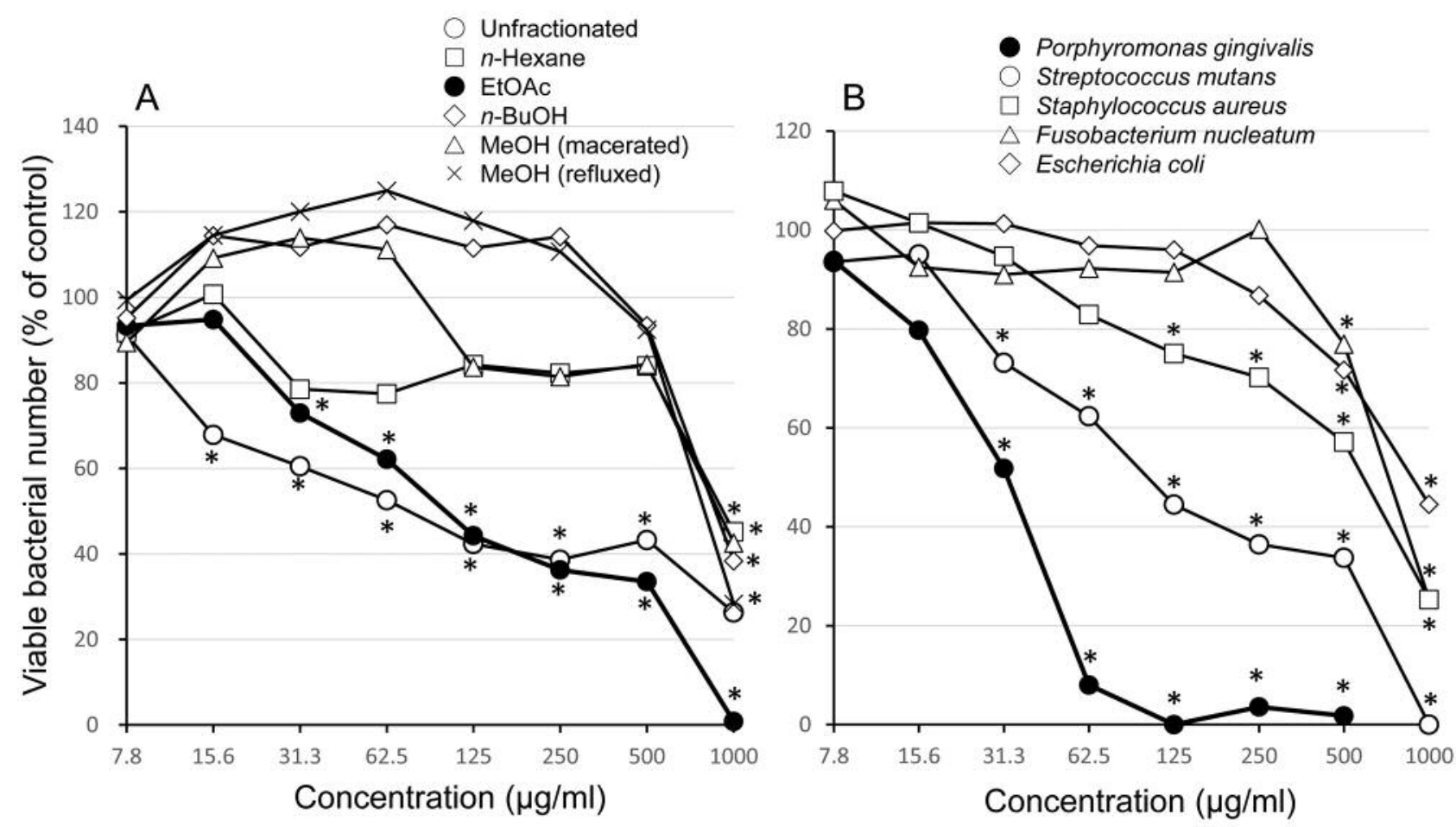

Figure 1. Antibacterial spectra of mastic extracts. A. Antibacterial activity of unfractionated $(\bigcirc), n$-hexane extract $(\square)$, ethyl acetate (EtOAc) extract $(\bullet)$, $n$-butanol $(\mathrm{BuOH})$ extract $(\diamond)$, methanol $(\mathrm{MeOH})$ extract (maceration $(\triangle)$, reflux $(\times))$ against Streptococcus mutans. B. Antibacterial activity of ethyl acetate (EtOAc) extract of mastic against Porphyromonas gingivalis (-), Streptococcus mutans $(\bigcirc)$, Staphylococcus aureus $(\square)$, Fusobacterium nucleatum $(\triangle)$ and Escherichia coli $(\diamond)$. Each point represents mean from three independent assays. *Significant reduction of viable bacterial number $(p<0.05)$.

Statistical treatment. Experimental values are expressed as the mean \pm standard deviation (SD). Statistical analysis was performed by using Student's $t$-test. A $p$-value $<0.05$ was considered to be significant.

\section{Results}

Mastic components were separated by organic solvents into $n$-hexane extract, ethyl acetate extract prepared following $n$ hexane extraction, as well as with methanol extract and $n$ butanol extract, either macerated or refluxed, as described in Materials and Methods, and subjected to assay for various biological activities.

Tumor specificity. All extracts showed higher cytotoxicity against four human oral squamous cell carcinoma cell lines (Ca9-22, HSC-2, HSC-3, HSC-4) ( $\mathrm{CC}_{50}$ ranged from 13.5 to $24.4 \mu \mathrm{g} / \mathrm{ml}$ ) as compared with three human normal oral cells (HGF, HPLF, HPC) (ranged from 28.1 to $84.8 \mu \mathrm{g} / \mathrm{ml}$ ), giving TS indexes from 1.4 to 2.6 (determined by the ratio of $\mathrm{D} / \mathrm{B}$ ) and from 1.3 to 2.3 (determined by the ratio of $\mathrm{A} / \mathrm{C}$ ) (Table I). Among them, ethyl acetate extract showed the highest TS values ( $\mathrm{TS}=2.6$ ), although its values were two-order lower than that of doxorubicin ( $\mathrm{TS}=244.7)$, which was used as positive control.

Antibacterial activity. All extracts significantly $(p<0.05)$ reduced the viable cell number of Streptococcus mutans in dose-dependent manners (Figure 1A). Ethyl acetate extract showed approximately eight or nine times higher antibacterial activity $\left(\mathrm{IC}_{50}=104 \mu \mathrm{g} / \mathrm{ml}\right)$, as compared with other fractions $(831-936 \mu \mathrm{g} / \mathrm{ml})$. It should be noted that ethyl acetate extract at $1,000 \mu \mathrm{g} / \mathrm{ml}$ completely eliminated the bacteria, while treatment with unfractionated sample retained $27 \%$ of the bacteria viable (Figure $1 \mathrm{~A}$ ). When $\mathrm{IC}_{50}$ value was divided by mean $\mathrm{CC}_{50}$ value against three human normal oral cells, SI values could be obtained (Table II). Ethyl acetate extract showed the highest SI value of antibacterial activity (0.813), followed by unfractionated $(0.587)>$ methanol (reflux) $(0.063)>$ methanol (coolly immersed) $(0.050)>n$-butanol $(0.034)>n$-hexane extractable fractions $(0.030)$ (Table II).

The most sensitive bacterial strain was Porphyromonas gingivalis $\left(\mathrm{IC}_{50}=32.7 \mu \mathrm{g} / \mathrm{ml}\right)$, followed by Streptococcus mutans $\left(\mathrm{IC}_{50}=104 \mu \mathrm{g} / \mathrm{ml}\right)$, Staphylococcus aureus $\left(\mathrm{IC}_{50}=609.4 \mu \mathrm{g} / \mathrm{ml}\right)$, 

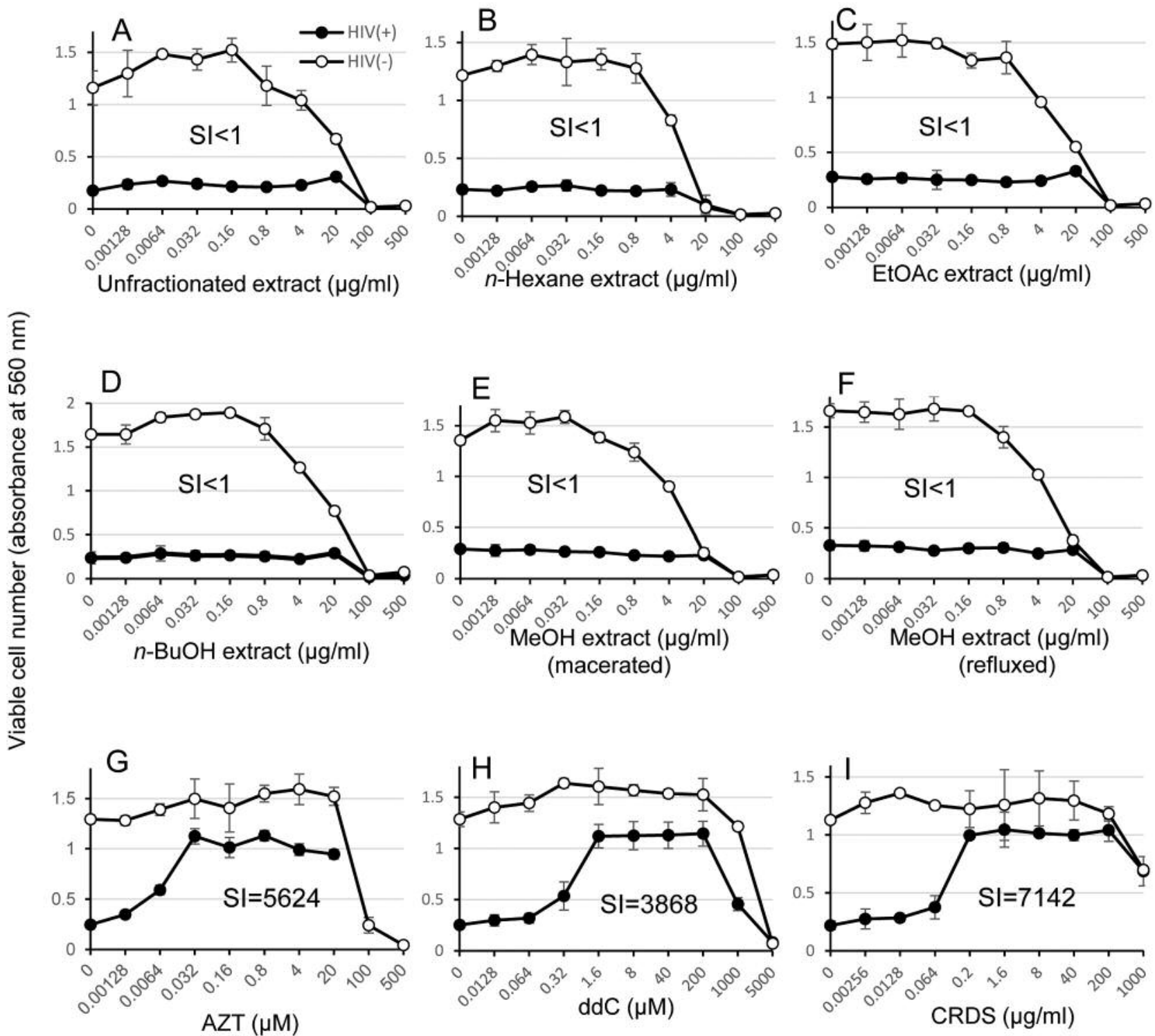

Figure 2. Anti-HIV activity of mastic extracts (A-F) and three popular anti-HIV agents (G-I). Mock- $(\bigcirc)$ or HIV- (๑) infected MT-4 cells were incubated for 5 days with the indicated concentrations of unfractionated (A) or n-haxane (B), ethyl acetate $(C), n$-butanol $(D)$, methanol extract (macerated, E; refluxed, $F$ ) extract of mastic or anti-HIV agents, AZT $(G)$, ddC $(H)$ or CRDS $(I)$. Viable cell number was then determined by MTT methods and expressed as absorbance at $560 \mathrm{~nm}$. Each value represents mean $\pm S D$ of triplicate assays. HIV, Human immunodeficiency virus; SI, selectivity index; EtOAc, ethyl acetate; $\mathrm{BuOH}$, butanol; $\mathrm{MeOH}$, methanol.

Fusobacterium nucleatum $\left(\mathrm{IC}_{50}=759.6 \mu \mathrm{g} / \mathrm{ml}\right)$ and Escherichia coli $\left(\mathrm{IC}_{50}=907.4 \mu \mathrm{g} / \mathrm{ml}\right)$ (Figure 1B).

Antiviral activity. When HTLV-I-bearing CD4-positive human T-cell line MT-4 cells were infected with HIV-1 $1_{\text {IIIB }}$ at a MOI of 0.01 , viability was reduced to $18.8 \pm 1.9 \%(n=9)$ of mock-infected cells (calculated by the absorbance value of control mock- and HIV-infected cells). All mastic extracts did not prevent HIV-induced cytopathic effects $(\mathrm{SI}<1)(\mathrm{A}-$
F), whereas three anti-HIV agents (AZT, ddC, CRDS) showed excellent anti-HIV activity ( $\mathrm{SI}=5,624,3,868,7,142)$ (G-I) (Figure 2).

When Vero cells were infected with HSV-1 (MOI=0.01), viability was reduced to $12.5 \pm 7.6 \%(n=6)$ of mock-infected cells (Figure 3 ). All mastic extracts partially but significantly $(p<0.05)$ reduced the HSV-induced cytophatic effects, recovering the cell viability up to $43.2 \pm 5.3 \%$ of mockinfected cells. Lower recovery of cell viability (less than 

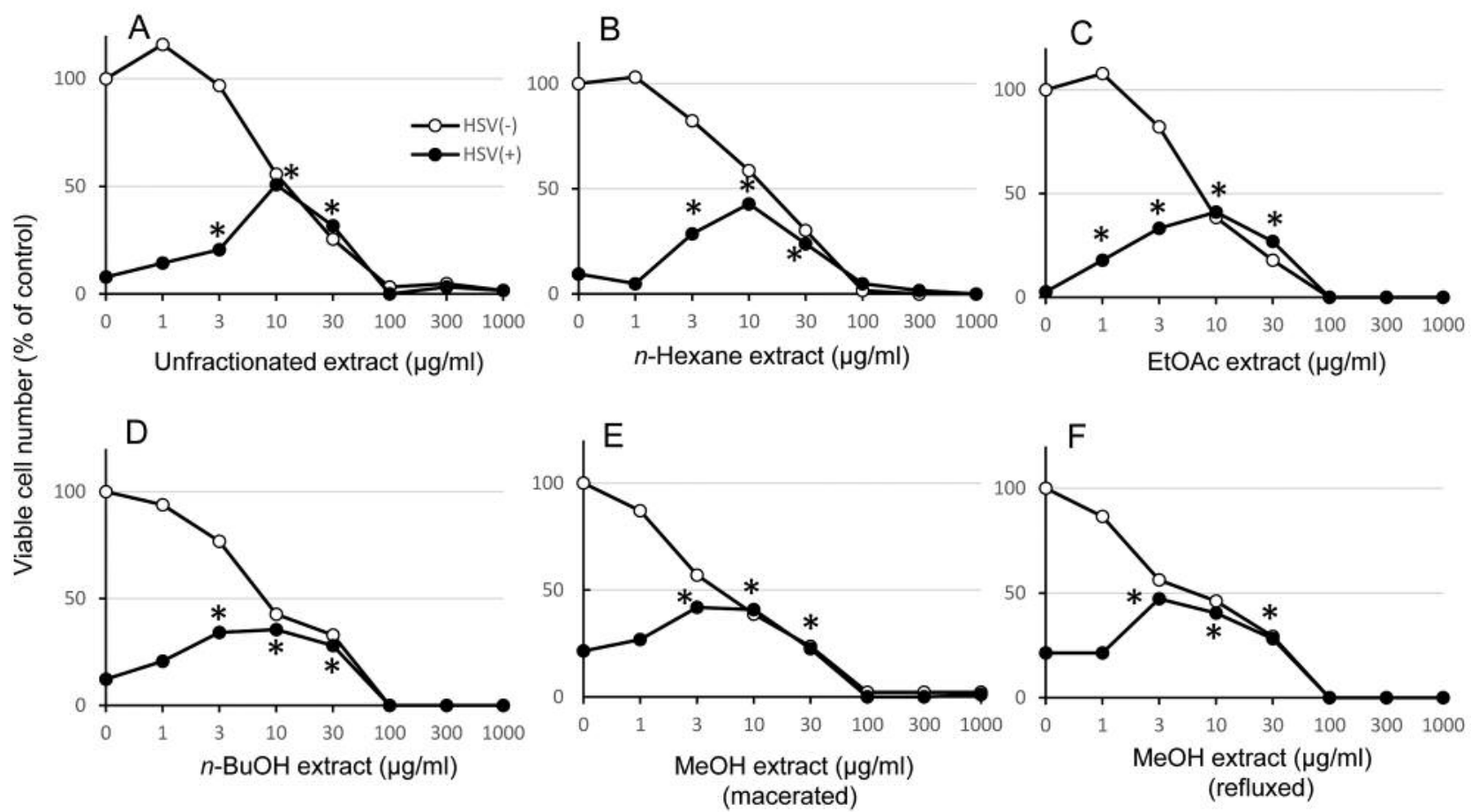

Figure 3. Anti-HSV activity of mastic extracts. Mock-(○) or HSV-(๑) infected Vero cells were incubated for 4 days with the indicated concentrations of unfractionated (A) or n-haxane (B), ethyl acetate (C), n-butanol (D), methanol extract (macerated, E; refluxed, $F$ ) extract of mastic. Viable cell number was then determined by the MTT method and expressed as \% of mock-infected control cells. Each value represents mean of triplicate assays. *Significant recover of viable cell number $(p<0.05)$. HSV, Herpes simplex virus; EtOAc, ethyl acetate; BuOH, butanol; MeOH, methanol.

$50 \%$ ) did not allow us to calculate the SI value. Higher concentrations of extracts reduced the anti-HSV activity, possibly due to the potent cytotoxicity of mastic (Figure 3).

CYP3A4 inhibitory activity. All mastic extracts were found to be potent inhibitors of CYP3A4, as judged from $\beta$ hydroxylation assay with testosterone (Figure 4$). n$-Hexane extract (B) exhibited the highest CYP3A4-inhibitory activity $\left(\mathrm{IC}_{50}=3.1 \mu \mathrm{g} / \mathrm{ml}\right)$, followed by methanol extract (macerated) $\left(\mathrm{IC}_{50}=4.1 \mu \mathrm{g} / \mathrm{ml}\right)(\mathrm{E}), n$-butanol extract $\left(\mathrm{IC}_{50}=12.1 \mu \mathrm{g} / \mathrm{ml}\right)$ (D), unfractionated sample ( $\mathrm{IC}_{50}=14.3 \mu \mathrm{g} / \mathrm{ml}$ ) (A), ethyl acetate extract $\left(\mathrm{IC}_{50}=14.8 \mu \mathrm{g} / \mathrm{ml}\right)(\mathrm{C})$ and, finally, methanol extract (refluxed) $\left(\mathrm{IC}_{50}=24.4 \mu \mathrm{g} / \mathrm{ml}\right)(\mathrm{F})$.

\section{Discussion}

The present study demonstrated, for the first time, that ethyl acetate extract of mastic prepared after $n$-hexane washing showed slightly higher antitumor ( $\mathrm{TS}=2.6)$ (Table I) and antibacterial activity $(\mathrm{SI}=0.813)$ (Table II) compared to unfractionated mastic ( $\mathrm{TS}=2.0, \mathrm{SI}=0.587$ ) (Table II). This may be due to the removal of cytotoxic substances by rinsing with $n$-hexane (Tables I and II). However, antitumor activity of all mastic extracts is much lower than that of anticancer drugs (TS=4-2,961) (25). It has recently been reported that the cytotoxic effect of antineoplastic drugs (cisplatin, 5fluorouracil and etoposide) against FTC-133 thyroid cancer cells was enhanced by essential oils from the aerial parts (leaves, twigs and berries) of Pistacia lentiscus (1). It, thus, remains to be investigated whether ethyl acetate extract of mastic and antitumor agents show such synergistic effect in the tumor cells.

It is surprising that mastic extracts show very potent CYP3A4 inhibitory activity. CYP3A4 is the most abundant CYP family (26) and, therefore, inhibition of CYP3A4 by mastic should increase the pharmacological action (in a good way) or side-effects (in a bad way) of concomitantly administered drugs. Washing out these CYP3A4 inhibitory substances with $n$-hexane may reduce these pharmacological action or side-effects of combined drugs.

We also found that ethyl acetate extract of mastic selectively killed Porphyromonas gingivalis. This microorganism has been reported to dominate the biofilm community (27), colonize the microbial flora around dental implants (28), be present into the saliva and pooled subgingival plaque samples of aggressive periodontitis (29) and Fanconi's anemia patients (30). Toothpaste that contains of mastic is available in Japan. Ethyl acetate extract of 

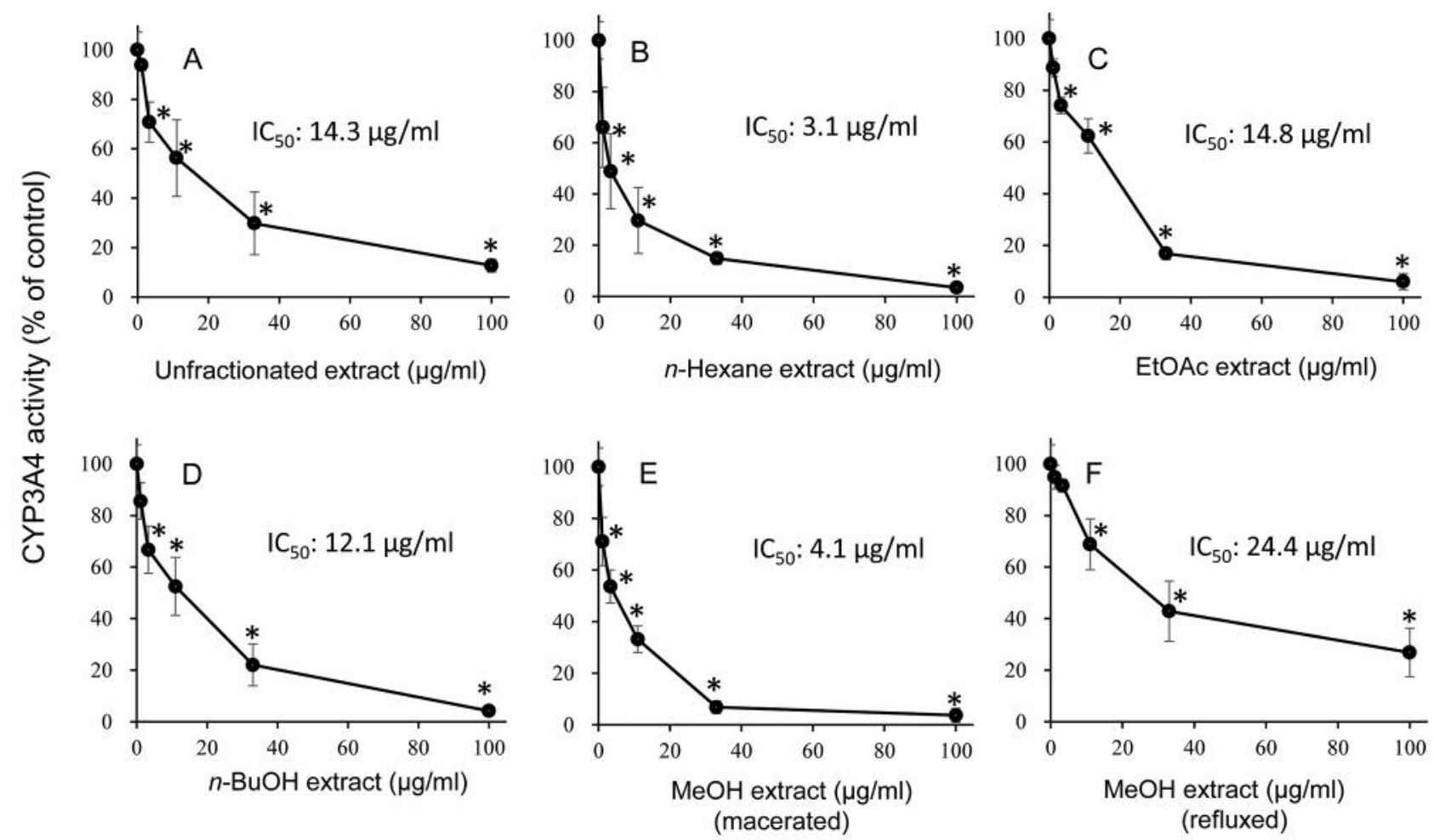

Figure 4. Cytochrome P450 enzyme (CYP)3A4 inhibitory activity of mastic extracts. Each value represents the mean $\pm S D$ of triplicate assays. EtOAc, Ethyl acetate; $\mathrm{BuOH}$, butanol; $\mathrm{MeOH}$, methanol; $\mathrm{IC}_{50}$, half-maximal inhibitory concentration. *Significant inhibition of CYP3A4 activity ( $\left.<<0.05\right)$.

Table I. Cytotoxicity and tumor specificity of mastic extracts.

\begin{tabular}{|c|c|c|c|c|c|c|c|c|c|c|c|c|c|}
\hline & \multicolumn{11}{|c|}{$\mathrm{CC}_{50}(\mu \mathrm{g} / \mathrm{ml})$} & \multirow{3}{*}{\multicolumn{2}{|c|}{ TS }} \\
\hline & \multicolumn{6}{|c|}{ Human oral squamous cell carcinoma cell lines } & \multicolumn{5}{|c|}{ Human oral normal mesenchymal cells } & & \\
\hline & (A) & & & & (B) & & (C) & & & (D) & & & \\
\hline & $\mathrm{Ca} 9-22$ & HSC-2 & HSC-3 & HSC-4 & mean & SD & HGF & HPLF & HPC & mean & SD & $(\mathrm{D} / \mathrm{B})$ & $(\mathrm{C} / \mathrm{A})$ \\
\hline Unfractionated & 22.4 & 26.9 & 16.8 & 27.1 & 23.3 & 4.8 & 43.9 & 22.8 & 76.4 & 47.7 & 27.0 & 2.0 & 2.0 \\
\hline$n$-Haxane extract & 21.5 & 18.6 & 22.2 & 18.0 & 20.1 & 2.1 & 28.6 & 24.5 & 31.2 & 28.1 & 3.4 & 1.4 & 1.3 \\
\hline EtOAc exract & 34.8 & 26.1 & 27.7 & 40.9 & 32.4 & 6.8 & 73.7 & 87.9 & 92.7 & 84.8 & 9.9 & 2.6 & 2.1 \\
\hline$n$-BuOH extract & 11.9 & 11.8 & 14.2 & 16.0 & 13.5 & 2.0 & 27.0 & 38.7 & 26.7 & 30.8 & 6.8 & 2.3 & 2.3 \\
\hline $\mathrm{MeOH}$ extract (Macerated) & 22.6 & 18.9 & 14.6 & 17.3 & 18.4 & 3.3 & 37.2 & 61.5 & 39.4 & 46.0 & 13.4 & 2.5 & 1.6 \\
\hline $\mathrm{MeOH}$ extract (Refluxed) & 26.8 & 25.8 & 21.1 & 23.7 & 24.4 & 2.6 & 36.9 & 67.9 & 53.0 & 52.6 & 15.5 & 2.2 & 1.4 \\
\hline DXR & 0.26 & 0.14 & 0.23 & 0.13 & 0.19 & 0.06 & 0.54 & 2.44 & 137.47 & 46.82 & 78.51 & 244.7 & 2.1 \\
\hline
\end{tabular}

HGF, Human gingival fibroblast; HPC, human pulp cells; HPLF, human periodontal ligament fibroblast; $\mathrm{CC}_{50}$, 50\% cytotoxic concentration; DXR, doxorubicin; TS, tumor specificity; EtOAc, ethyl acetate; $\mathrm{BuOH}$, butanol; $\mathrm{MeOH}$, methanol; $\mathrm{SD}$, standard deviation. Oral squamous cell carcinoma cell lines: Ca9-22 (derived from gingival tissue), HSC-2, HSC-3 and HSC-4 (derived from tongue). Each value represents mean of triplicate assays.

mastic, which has higher antibacterial activity than unfractionated mastic, may be appropriate for the treatment of periodontal diseases.

We found that mastic has some anti-HSV activity, but not anti-HIV activity, suggesting that the antiviral mechanism of mastic against these two viruses is different. Removal of cytotoxic substances may further enhance the anti-HSV activity, since anti-HSV activity seems to be masked by cytotoxic substances (judging from the overlap of loss of viability and that of anti-HSV activity; Figure 3). Further 
Table II. Antibacterial activity of mastic extracts.

\begin{tabular}{lccc}
\hline & $\begin{array}{c}\text { Antibacterial } \\
\text { activity } \\
\mathrm{IC}_{50}(\mu \mathrm{g} / \mathrm{ml}) \\
\text { Fractionation }\end{array}$ & $\begin{array}{c}\text { Cytotoxicity against } \\
\text { normal oral cells } \\
\mathrm{CC}_{50}(\mu \mathrm{g} / \mathrm{ml})\end{array}$ & SI \\
\hline Unfractionated & 81 & 47.7 & $(\mathrm{D} / \mathrm{A})$ \\
n-Hexane & 936 & 28.1 & 0.587 \\
EtOAc & 104 & 84.8 & 0.030 \\
n-BuOH & 900 & 30.8 & 0.813 \\
MeOH (Macerated) & 917 & 46.0 & 0.034 \\
MeOH (Refluxed) & 831 & 52.6 & 0.050 \\
\hline
\end{tabular}

SI, Selectivity index; EtOAc, ethyl acetate; $\mathrm{BuOH}$, butanol; $\mathrm{MeOH}$, methanol; $\mathrm{CC}_{50}, 50 \%$ cytotoxic concentration; $\mathrm{IC}_{50}$, half-maximal inhibitory concentration. Each value represents mean of triplicate assays.

studies are needed to elucidate the mechanism(s) of antiviral action and investigate the possible synergistic effect(s) of mastic with acyclovir.

\section{Conflicts of Interest}

This study was funded, in part, by Sunsho Pharmaceutical Co., Ltd (Hiroshi Sakagami), causing, however, no prejudice against the impartiality of the research reported.

\section{References}

1 Catalani S, Palma F, Battistelli S and Benedetti S: Oxidative stress and apoptosis induction in human thyroid carcinoma cells exposed to the essential oil from Pistacia lentiscus aerial parts. PLoS One 12(2): e0172138, 2017.

2 Piccolella S, Nocera P, Carillo P, Woodrow P, Greco V, Manti L, Fiorentino A and Pacifico S: An apolar Pistacia lentiscus L. leaf extract: GC-MS metabolic profiling and evaluation of cytotoxicity and apoptosis inducing effects on SH-SY5Y and SK-N-BE(2)C cell lines. Food Chem Toxicol 95: 64-74, 2016.

3 Hatamnia AA, Rostamzad A, Malekzadeh P, Darvishzadeh R, Abbaspour N, Hosseini M, Nourollahi $\mathrm{K}$ and Mehr RS: Antioxidant activity of different parts of Pistacia khinjuk Stocks fruit and its correlation to phenolic composition. Nat Prod Res 30: 1445-1450, 2016

4 Toul F, Belyagoubi-Benhammou N, Zitouni A and Atik-Bekkara F: Antioxidant activity and phenolic profile of different organs of Pistacia atlantica Desf. subsp. atlantica from Algeria. Nat Prod Res 31: 718-723, 2017.

5 Rauf A, Uddin G, Siddiqui BS, Khan H, Shah SU, Ben Hadda T, Mabkhot YN, Farooq U and Khan A: Antinociceptive and anti-inflammatory activities of flavonoids isolated from Pistacia integerrima galls. Complement Ther Med 25: 132-138, 2016.

6 Ahmad NS, Waheed A, Farman M and Qayyum A: Analgesic and anti-inflammatory effects of Pistacia integerrima extracts in mice. J Ethnopharmacol 129: 250-253, 2010.

7 Gholami M, Ghasemi-Niri SF, Maqbool F, Baeeri M, Memariani Z, Pousti I and Abdollahi M: Experimental and pathalogical study of Pistacia atlantica, butyrate, Lactobacillus casei and their combination on rat ulcerative colitis model. Pathol Res Pract 212: 500-508, 2016.

8 Tolooei M, Mirzaei A: Effects of Pistacia atlantica extract on erythrocyte membrane rigidity, oxidative stress, and hepatotoxicity induced by CCl4 in rats. Glob J Health Sci 7: 3238, 2015.

9 Koychev S, Dommisch H, Chen H and Pischon N: Antimicrobial effects of mastic extract against oral and periodontal pathogens. J Periodontol 88: 511-517, 2017.

10 Karygianni L, Cecere M, Skaltsounis AL, Argyropoulou A, Hellwig E, Aligiannis N, Wittmer A and Al-Ahmad A: Highlevel antimicrobial efficacy of representative Mediterranean natural plant extracts against oral microorganisms. Biomed Res Int 2014: 839019, 2014.

11 Miyamoto T, Okimoto T and Kuwano M: Chemical composition of the essential oil of mastic gum and their antibacterial activity against drug-resistant Helicobacter pylori. Nat Prod Bioprospect 4: 227-231, 2014.

12 Attoub S, Karam SM, Nemmar A, Arafat K, John A, Al-Dhaheri W, Al Sultan MA and Raza H: Short-term effects of oral administration of Pistacia lentiscus oil on tissue-specific toxicity and drug metabolizing enzymes in mice. Cell Physiol Biochem 33: 1400-1410, 2014.

13 Katsanou ES, Kyriakopoulou K, Emmanouil C, Fokialakis N, Skaltsounis AL and Machera K: Modulation of CYP1A1 and CYP1A2 hepatic enzymes after oral administration of Chios mastic gum to male Wistar rats. PLoS One 9: e100190, 2014.

14 Ezz Eldin HM and Badawy AF: In vitro anti-Trichomonas vaginalis activity of Pistacia lentiscus mastic and Ocimum basilicum essential oil. J Parasit Dis 39: 465-473, 2015.

15 Loizzo MR, Saab AM, Tundis R, Statti GA, Menichini F, Lampronti I, Gambari R, Cinatl J and Doerr HW: Phytochemical analysis and in vitro antiviral activities of the essential oils of seven Lebanon species. Chem Biodivers 5: 461-470, 2008.

16 Ozçelik B, Aslan M, Orhan I and Karaoglu T: Antibacterial, antifungal, and antiviral activities of the lipophylic extracts of Pistacia vera. Microbiol Res 160: 159-164, 2005.

17 Sakagami H, Kishino K, Kobayashi M, Hashimoto K, Iida S, Shimetani A, Nakamura Y, Takahashi K, Ikarashi T, Fukamachi H, Satoh K, Nakashima H, Shimizu T, Takeda K, Watanabe S and Nakamura W: Selective antibacterial and apoptosismodulating activities of mastic. In Vivo 23: 215-223, 2009.

18 Vlastos D, Drosopoulou E, Efthimiou I, Gavriilidis M, Panagaki D, Mpatziou K, Kalamara P, Mademtzoglou D and MavraganiTsipidou P: Genotoxic and antigenotoxic assessment of Chios mastic oil by the in vitro micronucleus test on human lymphocytes and the in vivo wing somatic test on Drosophila. PLoS One 10: e0130498, 2015.

19 Kantoh K, Ono M, Nakamura Y, Nakamura Y, Hashimoto K, Sakagami $\mathrm{H}$ and Wakabayashi $\mathrm{H}$ : Hormetic and anti-radiation effects of tropolone-related compounds. In Vivo 24: 843-852, 2010.

20 Sakagami H, Uesawa Y, Ishihara M, Kagaya H, Kanamoto T, Terakubo S, Nakashima H, Takao K and Sugita Y: Quantitative structure-cytotoxicity relationship of oleoylamides. Anticancer Res 35: 5341-5355, 2015.

21 Horikoshi M, Kimura Y, Nagura H, Ono T and Ito H: A new human cell line derived from human carcinoma of the gingiva. I. Its establishment and morphological studies. Jpn J Oral Maxillofac Surg 20: 100-106, 1974 (in Japanese). 
22 Miyoshi I, Taguchi H, Kubonishi S, Yoshimoto S, Otsuki Y, Shiraishi Y, Akagi T: Type C virus-producing cell lines derived from adult T cell leukemia. Gann Monogr Cancer Res 28: 219228,1982

23 Nakashima H, Murakami T, Yamamoto N, Sakagami H, Tanuma $\mathrm{S}$, Hatano $\mathrm{T}$, Yoshida $\mathrm{T}$ and Okuda $\mathrm{T}$ : Inhibition of human immunodeficiency viral replication by tannins and related compounds. Antiviral Res 18: 91-103, 1992.

24 Fukuchi K, Okudaira N, Adachi K, Odai-Ide R, Watanabe S, Ohno H, Yamamoto M, Kanamoto T, Terakubo S, Nakashima H, Uesawa Y, Kagaya H and Sakagami H: Antiviral and antitumor activity of licorice root extracts. In Vivo 30: 777-785, 2016.

25 Sakagami H: Biological activities and possible dental application of three major groups of polyphenols. J Pharmacol Sci 126: 92106, 2014.

26 Erratico CA, Deo AK and Bandiera SM: Regioselective versatility of monooxygenase reactions catalyzed by CYP2B6 and CYP3A4: Examples with single substrates. Adv Exp Med Biol 851: 131-149, 2015.

27 Kommerein N, Stumpp SN, Müsken M, Ehlert N, Winkel A, Häussler S, Behrens P, Buettner FF and Stiesch M: An oral multispecies biofilm model for high content screening applications. PLoS One 12: e0173973, 2017.
28 Herekar M, Sethi M, Prithviraj DR, Bhat K, Fernandes A and Patil V: A clinical study evaluating changes in the microbial flora around dental implants during various stages of implant restoration. Implant Dent 24: 527-532, 2015.

29 Feng X, Zhu L, Xu L, Meng H, Zhang L, Ren X, Lu R, Tian Y, Shi $D$ and Wang $X$ : Distribution of 8 periodontal microorganisms in family members of Chinese patients with aggressive periodontitis. Arch Oral Biol 60: 400-407, 2015.

30 Lyko K, Bonfim C, Benelli EM, Torres-Pereira CC and Amenábar JM: Salivary detection of periodontopathic bacteria in Fanconi's anemia patients. Anaerobe 24: 32-35, 2013.

Received May 10, 2017

Revised June 2, 2017

Accepted June 6, 2017 